Economics Development Analysis Journal 9(4)(2020)

\title{
An Analysis of The Sustainable Fishing Land Conservation Policy
}

\section{Nasikh ${ }^{凶}$}

Faculty of Economics, Universitas Negeri Malang, East Java, Indonesia

\begin{tabular}{l}
\hline Article Info \\
\hline History of Article \\
Received July 2020 \\
Accepted September 2020 \\
Pusblished November \\
2020
\end{tabular}

Keywords:

sustainable, fishing, land, development,

conservation, policy

\begin{abstract}
In order to implement the food sustainability and sovereignt, the sustainable fishing development has to be carried out. The research problem is how to analyze to sustain land conservation after the implementation of the Law number 23 in 2014 Pasuruan Regency, East Java, Indonesia. The specific aims of this analysis is to identify the implementation of the sustainable land conservation after the implementation of the Law number 23 in 2014 about the regional government, to identify the obstacle in the implementation of the policy, to identify the stabilizer of the implementation of the policy, and to propose recommendation of the policy strategy to be carried out by the regional government of Pasuruan, This study employs qualitative descriptive approach. The respondent of this study comes from farmer's, in which Pasuruan regency is represented by respondents of SKPD (Satuan Kerja Perangkat Daerah or Regional Work Unit) from Regional Development Planning Agency (henceforth Bappeda). The research finding shows that Overall, the implementation of the lahan pangan berkelanjutan or the Sustainable Food Land (henceforth LPB) has complied with the Law number 12011 despite the planning and decision of LPB in RTRW (spatial planning), the obstacle in LPB is the absence of regional regulation, the model of strategic policy; the regencies synergistically coordinate with each other, encouraging the development of pond reserve as well as the role of private sector and society, and the synchronization of the state budget and the regional government budget, and all regional governments have to protect all LPB areas complying with the Law number 12011 and its derivation, and the strategy to improve the welfare of the farmer is related to the instruments which have the lowest force intensity, namely market instrument, family and community, and voluntary organizations.
\end{abstract}

$\begin{array}{cccc}\text { C } & 2020 & \text { Universitas Negeri } \\ \text { Semarang } & & \end{array}$

${ }^{\circledR}$ Corresponding author :

ISSN 2252-6560

Address: : Department of Development Economics, Faculty of

Economics, State University of Malang Malang City, East Java,

Indonesia, J1 Semarang 5, Malang 65145

E-mail: nasikh.fe@um.ac.id 
Nasikh / Economics Development Analysis Journal 9 (4) (2020) 


\section{INTRODUCTION}

Indonesia is one of the developing countries that manages to improve its community welfare (Liliyawati \& Budhi, 2016) through the productive economic sector that is intended for the low-economic class community (Nasikh, 2017; Haryanto, et al. 2018). One of the attempts to improve the welfare is through People's Economy. It is based on the community's ability to manage the economy. As a consequence, the Indonesian government through the State-Owned Enterprises conducts Partnership Program and Community Development. The Partnership Program is considering more successful than other similar governmental programs that are intended to improve the community welfare (Haris, et al. 2015).

The economic development is generally defined as "a sustainable process that increases the community's per capita income in a particular country for a long term period" (Haris, et al. 2015). The development process is carried out continuously, accompanied by several improvements in order to improve the welfare of the community. Thus, the result of the development process is supposed to give impact to all communities. It is as a form of even and equally-distributed improvement of physical and spiritual welfare. The regional economic development is the process in which the government and community manage the existing resources and establish a partnership pattern between the local government and private sectors to create new job opportunities and stimulate the human resources development

to become more initiative and creative. With better quality of human resources, it is expected that they can contribute to the development process so that the economic development and community stability can be guaranteed.

A land conversion is a threat to the food security achievement. The land conversion has serious implication to the food production, physical environment, and farmers' welfare, and villages whose life depends on the land. The land conversion in the fertile area is not balanced by the integrated attempt to develop the land whose aims is to open newly potential areas (Aerts et al., 2017). In East Java Province, the land conversion leads to fewer areas to produce food which affects the farmer's welfare level. Therefore, the control to the agricultural land through the conservation becomes one of efforts to achieve the food security as well as improve the farmer's and society's welfare (Fischer et al., 2014; Godfray et al., 2010; Law et al., 2015; Lee, et al. 2014; Van Veldhuizen \& Waters-Bayer, n.d.).

The increasing number of the farming household is not comparable to the width of the pond land. Hence, the number of smallholder farmers who do not own any lands is growing in East Java. This affects to the difficulty to improve the farmer's welfare and alleviate poverty in the village (Governor Regulation of Pasuruan, East Java Number 13 in 2014). Further, the distribution of the Lahan Pangan Berkelanjutan (henceforth LPB) or the Sustainable Food Land in regency Pasuruan. Several policies have been issued by the government to encourage the supply of the sustainable food land (De Groot, 2006; FAO, 2014; Grau, et al. 2013; Mertz \& Mertens, 2017; Phalan, et al. 2011; Tscharntke et al. 2012). It includes giving away incentive and conservation as well as implementing productive land conservation. The aim is clearly stated to prevent the pond land from getting decreased. If it decreases, it will affect directly to the food supply. However, the pond land conversion warning does not work as it is expected. Despite the fact that it has been stated in the law, the warning is still difficult to be implemented. The pond land changes its function to be residence area, shopping mall, and office building. The regional government, particularly the regency/city as the owner of the land, prefers utilizing the lands for the projects which are more profitable to the regional government budget to functioning it as pond land. The Bappeda Agency managed to open 330 million hectares of new rice fields during 2006 to 2013 or 40 thousand hectares each year. The ability to 445 
open the fish field is not comparable to the fish filed conversion rate which is in the level of 100 thousand hectares per year.

Regarding to the regional government of Pasuruan's performance in establishing the width of the sustainable food land as it is mandated in the Law number 12011 and the Government Regulation number 1 (2011), they have carried out four coordination meetings to establish the LPB with the regency/city government. According to the background of the study and some considerations, the research problem is as follows. First, what factors obstruct the implementation of the sustainable food land conservation policy in Pasuruan, East Java which complies with the Law number 23 in 2014 about the Pasuruan Regional Government? Second, what policies the regional government of Pasuruan, East Java can apply which complies with the Law number 23 in 2014 about the Pasuruan Regional Government?

The definition of sustainable development based on the Report of the World Industry Conference on Environmental Management (1984) is a development which is oriented to meet the need of the present generation without sacrificing the capability of the future generation to fulfil their needs. According to Suryana (2005) there are four principles to achieve the goal of the sustainable development, namely (1) the fulfillment of basic needs, (2) the ecology integrity maintenance, (3) the social justice, and (4) the opportunity to determine one's fate. According to the definition of the sustainable development from WCED, the Food and Fishing Organization defines the sustainable food land as the natural resources-based management, conservation and technological changing orientation to meet the need of the present and future generations. The sustainable food development conserves land, water, plants, and animals as well as conserves the environment. It is also technically efficient, economically feasible, and socially accepted (FAO, 1989). The law of the state land admits and respects the citizen's right to their land and belongings related to the land and they give public authority to the country by issuing regulation, policy, and management as well as monitoring its implementation in the principles of land acquisition (Nasikh, Hakim L, 2015; Nasikh, 2018; the Law Number 12 in 2012; Jat, et al. 2019d).

The sustainable food is a resource management to produce the basic need of human being, namely clothing, food, and housing as well as maintaining and improving the quality of environment. This definition includes these points. First, it is stable ecologically. Second, it can be sustainable economically. Next, it is fair. Fourth, it is humane. The last is it is flexible. The control of the sustainable food agricultural land is managed by the central and regional governments by the incentive. The incentive is a form of attention and reward of the government to the farmer whose land is converted into the sustainable food fishing land (The Law number $12011)$.

Based on the Government Regulation number 12 (2012) about the sustainable food fishing land conservation, incentive is given to the farmer as the reward for them. As it is explained in the Law number 12011 about the sustainable food fishing land conservation, the land is controlled by the central and regional governments by giving incentive. The incentive given to the farmer can be in the form of tax reduction, fishing infrastructure development, seed development and research funding, fishing production facility provision, and the issuance of the freehold title guarantee.

The funding of the sustainable food fishing land conservation aims at guaranteeing the availability of the sustainable food fishing land which is done by the central, province, regency/city governments as well as business actors. The scope of this government regulation includes the funded activity, fund resources and form, as well as the implementation of the funding. The fund comes from the central, province, regency/city's budget as well as the business entities and the society to implement the sustainable food fishing land conservation The implementation of sustainable fisheries 
development in relation to the implementation of the Law number 23 in 2014, especially spatial planning. This has resulted in decreased environmental quality and function. The existence of fishery resources and other resources determines daily human activities. Human activities greatly affect the existence of natural resources and the environment around them. The damage to fishery resources is largely determined by human activities. Many cases of environmental damage are caused by human activities such as water and soil pollution and damage to fishery resources. The research problem is how to analyze to sustain land conservation after the implementation of the Law number 23 in 2014 Pasuruan Regency, East Java, Indonesia. (Ditzler, et al. 2019; Jat, et al. 2019a Government Regulation number 30 in 2012; Jat, et al. 2019c; Smith, et al. 2017; Pujiati. \& Imron, 2020; Tscharntke, et al. 2012; Waridin, et al. 2019).

The availability of land for fishing is an absolute requirement to play the role of the fishing sustainably, particularly its role to achieve the national food security, selfsufficiency, and sovereignty. On the other side, philosophically, the land plays the role and central function for the society of Indonesia who is well-known as agrarian as it has the economic, social, cultural, and religious values. The problem is the high pressure to the land. It is due to the fact that the number of population grows as much as $1.49 \%$ per year, while the land width is relatively unchanging. This is also worsened by the productivity of the fishing land which is leveling off, the competition to utilize the land for building, and the expansion of province and regency/city areas. These all make the availability of land to meet the national food need threatened (Nasikh, 2017; The Government Regulation number 1, 2011; Central Bureau of Statistics of East Java in Numbers, 2020; Jat, et al. 2019b; Das. et al. 2015).

The compensation for the land acquisition is given directly to the rightful party. It is given based on the rating result decided by the discussion forum and/or the District Court or Supreme Court. When the compensation is given, the party receiving it has to (1) release their ownership right and (2) hand over the proof of ownership to the other party who takes the land through the Land Agencies (Franzel \& Houten, 1992; Kremen, 2015; The Government Regulation number 12, 2012).

In order to meet the funding system and the process of the sustainable food fishing landconservation, there are three main principles which are required in the policy of fundingthe sustainable food fishing landconservation. First, the funded activities are related to the planning and establishment, developing, research, utilization, controlling, monitoring, information system, as well as the farmer protection and empowerment which are the part of the sustainable food fishing landconservation. Another principle is the funding resources and forms are from the State Budget and Regional Government Budget which are used to fund the necessary activities according to the law. Finally, the principle of the implementation of the funding of the sustainable food fishing land conservation has to be done as well. Community participation can guarantee dynamism in environmental protection and management. In reality, as long as the authority for environmental management is delegated to the regions, especially in Pasuruan Regency. The environmental conditions of fisheries resources becDresslerome clear. Therefore, it is very interesting to study and analyze to sustain land conservation after the implementation of the Law number 23 in 2014 Pasuruan Regency, East Java, Indonesia.

\section{RESEARCH METHODS}

The study is carried out in some stages. The first stage is called pre-field stage that involve planning, choosing the research setting, arranging research permits, approaching the research setting, and preparing the tools. The next stage is implementation. It is a step to obtain data through the interview with informants and documentation which are later used for data analysis. This research method is qualitative with a case study. The author 
explores a limited system (case) on sustainable fisheries development with the implementation of Law No. 23 in 2014 Pasuruan Regency, East Java through detailed and in-depth data collection involving various sources of information namely observations, interviews, documents and reports (Ditzler, et al. (2018); Ditzler, et al. (2019); Jat, et al. (2019)).

This study employs a descriptive study which aims at describing facts and the characteristics of LPB in regency of Pasuruan, East Java Province systematically and accurately. In Pasuruan regency, the productive fishing land gradually decrease due to the rapid development of industry and there is no balance between them. This phenomenon is actually due to the loose monitoring of the productive fishing land done by the regional government. In the Government Regulation number 12 (2012) about the incentive of the sustainable food fishing land conservation, the citizen or farmers can receive incentive from the government if they can maintain the productive fishing land. The data sources are taken from the field. The data are divided into primary and secondary data. The data collection is carried out by observation, in depth interview, questionnaire, and documentation. Pasuruan regency is chosen based on the consideration that they can represent the big regency in East Java. The respondent of the study comes from pasuruan regency, in which respondents from SKPD (Satuan Kerja Perangkat Daerah) of Bappeda and fishing Agency.

In data collection, the author employs a few methods, including the interview method. The interview is unstructured one in which the author only prepares the written question list without any answer options so that the respondents are allowed to give answers according to the real condition. The data collection technique is triangulation I (compilation) which uses various data collection techniques simultaneously. While analysis technique uses the policy recommendation analysis to analyze the sustainable food fishing land conservation using the qualitative analysis model (Convention on Biological Diversity,
1992; Makate,et al.2016; Miles \& Huberman, 1984, Jat, et al. 2018).

\section{RESULTS AND DISCUSSION}

The sustainable food fishing land conservation was set in the Law number 12011. It was defined as the fishing land which was established to be conserved and developed consistently to produce staple food for the sake of the food security, self-sufficiency, and sovereignty.

One of the sectors whose resource potential has not been optimized yet is a fishery sector. It plays a potential role to drive the economic growth and development in East Java, especially in Pasuruan regency where the fishery becomes a potential sector. Supply of fish to meet the regular food need contributes to the increased sustainable food security.

East Java is one of the potential areas to develop the fishery sector. According to Central Bureau of Statistics of East Java in Numbers (2020) the length of East Java's coast is 2,128 kilometers. Along the coast, there are a lot of natural resources with good potential to support the sustainable regional development-if they are well managed. The northern coastal area of East Java is generally employed to sea transport, natural preservation, and fisherman settlement. It is located in Pasuruan, East Java. An environmental-friendly fishery development in Pasuruan regency becomes one of regional attempts to improve the economic condition. It is an asset and capital with higher comparative excellence and competitiveness than other regencies. It favors the market competition which results in increased income and welfare of fish farmers. Furthermore, the abundant fishery product does not guarantee the fish farmers' welfare in a long-term period, unless it is balanced by the sustainable and environmentalfriendly land development.

The environmental-friendly fishery development is the most ideal capital and management for the fishery resources as it can increase production without degrading the existing ecosystem. It can be done when there 
are some fishery production factors, namely land, capital, and labor. It applies to traditional, semi-intensive, and intensive fisheries by referring to environmental impact analysis.

The environmental-friendly land use highly encourages the sustainable land development. One of the examples in the fishery sector is technologies used by the fish farmers. It is whether they employ the modern technology or they integrate modern technology and traditional methods or they maintain the traditional ways (no technology at all) without damaging or degrading the fishery land quality.

Pasuruan regency is one of the regencies in East Java that has many potential sectors in its lowland and highland. Particularly for some sub-districts in the coastal area of Pasuruan regency, the community works in the fishery sector. It is no longer a secret that economic production (of fishery sector) has an inverse relation with the environmental quality. The increased production of fishery sector gives higher income to the fish farmers. It affects the existing resources significantly, especially the fishery land resource and other resources. However, welfare has not indicated the economic and ecological balance yet. Studies and discussions about economic and ecological balance are interesting to be discussed comprehensively in order to create simultaneous balance. The economic and ecological balance is very essential to be monitored as it is one of the development strategies and purposes of Pasuruan regency. Consequently, it is important to decide how to balance the economic and ecological aspects as well as how to minimize the environmental damage to achieve economic and ecological balance, thus, the fishery sector can have the competitive excellence and become the example for other sectors.

Environmental-friendly land management and development in the fishery sector aims to maintain the environmental functions as the land is utilized by the fish farmers. The environmental-friendly resource management is carried out by maintain the biological resources, such as mangrove. Fish cultivation in the coastal area of Pasuruan regency is highly related to the urban planning, social and culture, safety, and economic condition of the community in this area. The fishery business design is one of the main factors determining the success of land cultivation and development that applies the environmental-friendly principle.

Environmental-friendly is a perspective towards the living environment. It is an ability to comprehend ways to adapt or engage with the living environment. The living environment consists of three components, namely abiotic or physical component (water, air, and soil), biotic or biological component (flora, fauna, microbe, and their elements), and cultural component (social, economy, and culture).

In order to apply the environmentalfriendly principle, there are some activities to be carried out; (a) Closed recirculation system; it aims to keep the metabolite and toxic elements from polluting the environment. It can be done by the filter system; (a.1) Biological filter system can be applied by using nitrification bacteria, algae, or water plants to employ ammonia or other organic compounds; (a.2) Non-biological filter system can be carried out in physics or chemistry manner to the same pollutant; (b) Mangrove is utilized to decrease the waste content of fish cultivation. It is a bioremediation in the closed fish cultivation. The study and discussion in this paper is about the waste content (mangrove). This positive tendency will be developed continuously in order to achieve a new, environmental-friendly standard design and cultivation technology; (c) Biocontrol bacteria or probiotic can be used to decrease the use of antibiotic so that water pollution is minimized; (d) Transgenic uses isolated cecropin gene from bombyxmori silkworm. The transgenic fishery commodity which contains cecropin recombinant will have a high spot activity towards pathogen bacteria in the fishery commodity; (e) Organic fertilizer is used in order to improve the soil structure in the fishery business. Thus, the soil becomes better colloid and the organic fertilizer will create mineral balance.

LPB could be in the form of irrigated land, land reclamation of tidal swamp and non- 
tidal swamp, and non-irrigated land. In the present time, the productive fishing land in Pasuruan regency was 35.000 hectares with the fish productivity rate as much as 203.000 tons in 2013 and it increased from year to year (Nasikh, (2018); Nasikh \& Hakim, (2015); Pradnya, (2014); Wirawan \& Arka, (2015); Jat, et al. (2019); Smith, et al. (2017); Francis, et al. (2017))

The strategy and stimulant to implement the sustainable food fishing landwhich was a part of the establishment of the regional planning in the regency/city has complied with the Law number 1 2011. It was carried out with the strategy to prevent the landfunctional shift. The strategy was as follows the development of social-economy-culture-and-ecosystem-based regional planning; the establishment of strategy and approach to control the functional shift of irrigated land; the establishment of "permanent" zoning for the irrigated fish field; the government regulation as the instrument of legal protection to the permanent zoning of the irrigated land (Butsic, et al. (2015); Nasikh, (2013); Nasikh , (2014); Windy, (2014); Defrancesco, et al. (2018); Bernard, et al. (2014); Choudhary, et al. (2018); Kumar, et al. (2018); Francis, et al. (2017)).

The evaluation result of the overall LPB aspects which is mandated in the Law number 1 2011 in Pasuruan regency which become the research setting is as follows table 1 .

Table 1. The Evaluation of the Overall LPB Aspects in This Research Settings

\begin{tabular}{ll}
\hline LPB Aspect & LPB Implementation \\
\hline Planning and Establishment & It is not well-planned, the establishment of LPB is mostly in \\
& RTRW not RDTR \\
Development & Mostly is routine program, not LPB \\
Research & The this regencies have conducted it \\
Utilization & The part of routine, not LPB \\
Supervision & The part of routine, not LPB \\
Controlling & The incentive has not been related to the LPB program \\
Monitoring & There has not been a complete LPB reporting system \\
Information System & There has not been a complete LPB information system \\
Conservation and Empowerment of & \\
Farmers & Mostly is routine program, not LPB \\
Funding & The LPB research has been done and funded by the Regional \\
Society's Role & Budget \\
Administration Sanction & The society has not been involved maximally \\
\multicolumn{1}{c}{ Source: Balmford, Green, \& Scharlemann, 2005; Dressler, et al. 2016; Egan \& Mortensen, 2012} \\
Leventon \& Antypas, 2012; Phelps, et al, 2013; Pirard \& Belna, 2012; Rai \& Bawa, 2013
\end{tabular}

The main target of development is the establishment of strong fundamental to the economic structure to grow and develop its own power to achieve the equitable and prosperous community according to the national ideals (Yudha \& Wahyu, 2013; Ditzler, et al. 2018). The wider job opportunity is required to balance the population growth rate, especially the youth in productive ages who enter the labor market. The inadequate job vacancies will cause unemployment that can bring more significant issues (Rasyid, 2016). Basically, the economic development is a set of attempts to increase the community's income, create wider job opportunities, distribute equal income, improve inter-region relations, and shift the economic activity from the primary sector to secondary and tertiary sectors (Kusumawardhani, et al. 2015). It is intended to give positive changes to all aspects, including the economy, social, culture, infrastructure, and so forth. The final purpose of the economic development is to achieve the community welfare. The development in the developing countries 
emphasizes on the economic development. It allows the goal achievement, encourages changes, and renews other life aspects (Mentayani \& Rusmanto, 2016; Ali, 2013; Choudhary, et al. 2017).

A good economic development planning requires a careful planning in utilizing the public and private resources and sectors that play significant roles in the process. Through the directed planning, tax payment, capital investment, and great economic weather, the good regional development can be achieved as a unit that is interrelated (Yudha \& Wahyu. 2013; Rodhiyah, 2015).

The economic growth means that there is increasing Gross Domestic Product/ Gross National Product regardless the population growth rate. There are three factors that affect the growth rate, namely capital accumulation, population growth, and technology advancement. In order to increase the economic growth through the effective and efficient economic development, the economic development should be directed to economic and other sectors as a whole (Kurniawati \& Mukzam, 2017; Kurniasih \& Rodhiyah, 2016; Choudhary, et al. 2018).
The increasing economic activities on the basis and potential sectors will improve the Gross Regional Domestic Product as well. It is due to the fact that the sector or Subsector specialization in each region can increase community's effectiveness and efficiency in the economic activity (Zulfikar, 2017). Job opportunities and income in the basis sectors are demanding functions that are exogenous (it is independent from the internal power or local demand). Meanwhile, the non-basis activity exists to meet the local consumption, thus, it is highly affected by the increasing income of the community (Rahmini, 2017; Suprayitno, et al. 2013; Susilo, 2014; Wijaya \& Yuniati, 2014; Ciliberti \& Frascarelli, 2018). Based on the table 1 above, it was shown that the government's concern to the food issue is very high, yet their concern to the farmer's welfare is still very low (Chandler et al., 2013; Reed et al., 2009; Ditzler, et al. 2019). The instrument of the policy is not effective. The farmer becomes the tools or reasons. The attempt to improve the farmer's welfare should be carried out by improving the quality of human resources setting is as follows figure

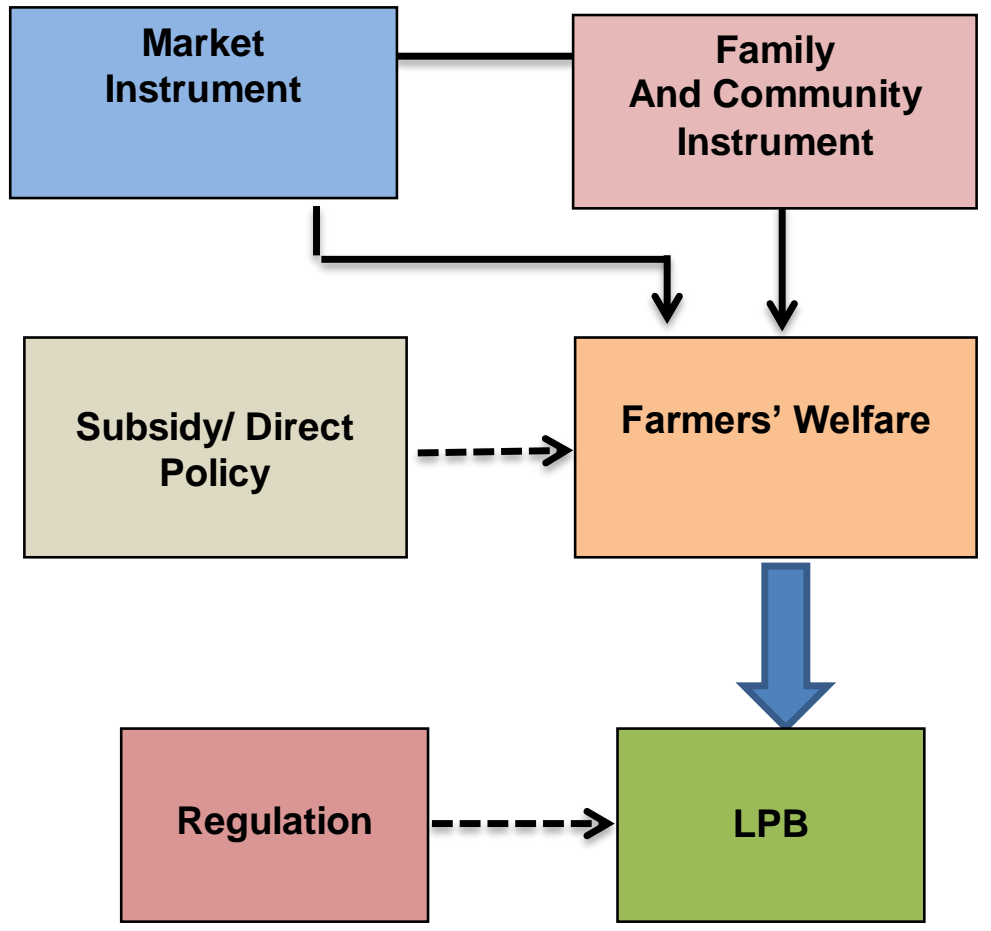


Figure 1. The Proposed Model of Policy Instrument of the Sustainable Food Fishing Land Conservation in Pasuruan Regency, East Java, Indonesia

Source: Dressler, et al. 2016; Egan \& Mortensen, 2012; Leventon \& Antypas, 2012; Phelps, et al, 2013; Pirard \& Belna, 2012; Rai \& Bawa, 2013; Tadesse, Zavaleta, Shennan, \& FitzSimmons, 2014

Based on the figure 1 above, it was shown that the policy of the sustainable food fishing land conservation has to be able to improve the welfare of the farmer as the main purpose of the policy.

In order to add more fish production in the coastal area, aquaculture should be conducted (Defrancesco, et al. 2018; Bernard, et al. 2014; Choudhary, et al. 2018; Nasikh \& Hakim, 2015; Pradnya,2014; Wirawan \& Arka, 2015; Jat, et al. 2019a) give a definition of aquaculture. It is either artificial or natural fish growth through environmental manipulation to increase production. It is carried out for certain types of fish in rivers, lagoons, and estuaries.

Rich natural resource potential leads to the rapid development of economic activities. Thus, it is prone to an excessive exploitation. As a result, the coastal area is susceptible to negative environmental changes, such as pollution, sedimentation, hydrological change, and biodiversity degradation (Rahmini, 2017; Suprayitno, et al. 2013; Susilo, 2014; Wijaya \& Yuniati, 2014; Ciliberti \& Frascarelli, 2018; Nasikh, 2014; Phelps, et al, 2013). They decrease the coastal endurance against the sea wave, so abrasion and environmental damage can occur. In order to maintain the economic growth, the development of fishery sector has to stabilize the coastal economic potential and minimize the environmental problems that can occur in the future as a result of coastal resource utilization (Kurniawati \& Mukzam, 2017; Kurniasih \& Rodhiyah, 2016; Choudhary, et al. 2018).

According to Nasikh \& Hakim, 2015; Pradnya,2014; Wirawan \& Arka, 2015; Jat, et al. 2019a; there are some economic and ecological dimensions that should be considered by the fishery sector, particularly in Pasuruan regency. They are global change and globalization. Technology, communication and telecommunication, and transportation advances reinforce the globalization, so the economic relation among countries and regions becomes easier. In addition, the government support in forms of custom clearance promotes free trade. As a consequence, it is compulsory for every businessman to improve his performance to generate competitive products and services. On the other hand, ecological issues occur, such as soil degradation and soil potential degeneration (Nasikh \& Hakim, 2015; Pradnya,2014; Wirawan \& Arka, 2015; Jat, et al. 2019a; Susilo, 2014; Wijaya \& Yuniati, 2014; Ciliberti \& Frascarelli, 2018). Furthermore, intensively cultivated land for the fishery sector cannot be employed anymore after certain years. Instead, it should be in the 'non-function' mode for a year or two. It is in order to neutralize the land content off the excessive pesticide, fertilizer, and food. It is important to maintain the economic and ecological balance.

According to Rahmini, 2017; Suprayitno, et al. 2013; Susilo, 2014; Wijaya \& Yuniati, 2014; Ciliberti \& Frascarelli, 2018; the increasing production does not ensure the fish farmers' income in a long-term period if there is no environmental-friendly improvement. The positive effect of environmental-friendly land development is proper commodity prices and good skill management of fish farmers.

The geographical situation of Pasuruan regency is mostly lowland. It makes this regency excellent for fishery sector. Environmentalfriendly fishery development is one of the regional attempts done by the regional government to develop sustainable fishery land with its fishery potential. It is one of the potential sectors with higher comparative excellence and competitiveness than other regencies. It favors the market competition which results in increased income and welfare of fish farmers (Suprayitno, et al. 2013; Susilo, 
2014; Wijaya \& Yuniati, 2014; Ciliberti \& Frascarelli, 2018; Nasikh, 2018; Wirawan \& Arka, 2015; Jat, et al. 2019a).

To date, the main concern of the regional community especially in Pasuruan regency is how to accelerate fish farmers' income without damaging the environment. The relevant stakeholders and policy makers constantly prioritize the economic growth in the fishery sector (Wijaya \& Yuniati, 2014; Ciliberti \& Frascarelli, 2018; Nasikh, 2018; Wirawan \& Arka, 2015; Jat, et al. 2019a). In the end of year, they compile, review, and evaluate data they have collected (statistical data related to the economic growth in Pasuruan regency). They wish to achieve excellent economic growth. Nevertheless, the good economic development with poor environmental improvement will decrease the resource productivity. In the context of fishery sector, there will be a degradation of land resource. Therefore, a balance in economic and ecological developments is required. Economic development and environmental sustainability are the central theme of economic and ecological aspects in all regions in Indonesia, including Pasuruan regency (Susilo, 2014; Wijaya \& Yuniati, 2014; Ciliberti \& Frascarelli, 2018; Nasikh, 2018; Wirawan \& Arka, 2015; Nasikh, 2018).

The regional income that applies the economic and environmental approach is a benchmark of success in integrating the economic and ecological aspects, including in Pasuruan regency. Thus, the regional economic growth based on the sustainable economic development is a process to increase the regional economic production capacity that is realized in the form of increased regional income without degrading the environment or the existing resource quality. As the regional economic growth becomes the benchmark of regional welfare, the assessment to the regional income has been widely applied. Therefore, we cannot be left behind and we have to keep learning about the essence and source of regional income (Rahmini, 2017; Suprayitno, et al. 2013; Susilo, 2014; Wijaya \& Yuniati, 2014; Ciliberti \&
Frascarelli, 2018; Nasikh, 2018; Wirawan \& Arka, 2015; Jat, et al. 2019a; Smith, et al. 2017; Francis, et al. 2017b).

The regional development which takes economic and ecological balance into account will encourage the sustainable economic development. According to Ditzler, et al. 2019; Jat, et al. 2019a; Smith, et al. 2017; Pujiati. \& Imron, 2020; Tscharntke, et al. 2012; Waridin, et al. 2019; it is because the region is able to identify the potential sectors of its own. Then, it analyses the added value of the regional economic development. The realization of development purpose has to be carried out in a proper, comprehensive, and integrated manner. It includes planning, implementation, and evaluation. Therefore, the regional autonomy will be able to improve the fish farmers' welfare (Wijaya \& Yuniati, 2014; Nasikh, 2018; Wirawan \& Arka, 2015; Dressler, et al, 2016; Fotourehchi, 2017; Mertz \& Mertens, 2017; Egan \& Mortensen, 2012).

However, the sustainable development in the fishery sector finds some obstacles. One of the examples is income gap among fish farmers. Wijaya \& Yuniati, 2014; Nasikh, 2018; Wirawan \& Arka, 2015; believe that the central area of a region tends to have bigger opportunity to develop than the urban area. As a result, the regional gap occurs. In addition, Wirawan \& Arka, 2015; Wirawan \& Arka, 2015; Egan \& Mortensen, 2012; state that the rapid population growth in the rural areas becomes the main factor causing the degradation of fish farmers' welfare. Higher population density leads to some issues, namely lack of education access, increased unemployment, and low capital. They cause low income per capita. Despite the fact that the fish farmers live in the same area, they have different source and pattern of income. It is influenced by types of occupations, education level, and etcetera (Green, \& Scharlemann, 2005; Dressler, et al. 2016; Egan \& Mortensen, 2012; Nasikh \& Hakim, 2015; Pradnya, 2014; Wirawan \& Arka, 2015).

The implementation of a policy is a very important factor in determining the success of the sustainable fisheries development policy 
with the implementation of Law No. 232014 in Pasuruan Regency, East Java. Based on the research results indicate that knowledge and understanding of sustainable fisheries development with the implementation of Law No. 232014 can implement. This condition shows that policy actors know and understand

\section{CONCLUSION}

To improve the farmer's welfare, there should be some policy instruments whose force intensity is the lowest. The instrument to be considered is market instrument, family and community instrument, as well as voluntary organizations. While the instrument in the form of regulation is the complement which is done by establishing LPB in RTRW to strengthen the limit of the land use. Thus, there is certain location for all. The subsidy and direct policy can be continually applied, but it has to be gradually decreased along with the increased participation and farmer's self-sufficiency. The complemented instrument which relies on the state authority has to be gradually decreased and it has to determine the direction of the government policy.

This paper was supported by Ministry of Agriculture of Republic Indonesia. We would like to thanks to DRPM Ministry of Education and Culture, Indonesia; LP2M and Faculty of Economics, State University of Malang (Universitas Negeri Malang), East Java, Indonesia and UPT BPAL Subdistrict Bangil, Pasuruan Regency, East Java Province, Republic of Indonesia.

\section{REFERENCES}

Aerts, R., Geeraert, L., Berecha, G., Hundera, K., Muys, B., De Kort, H., \& Honnay, O. (2017). Conserving wild Arabica coffee: Emerging threats and opportunities. Agriculture, Ecosystems and Environment, 237, 75-79. https://doi.org/10.1016/j.agee.2016.12.023

Ali, A. (2013). "Six Insecticide Pillars" Policy of Partnership-Based SMEs Development with CSR Pattern as a Strategy to Improve the Government's Role and Company to Maintain the Existence of SMEs in MEA about sustainable fisheries develop (Ciliberti \& Frascarelli, 2018; Butsic, et al. 2015; Nasikh, 2013, Nasikh 2014; Windy, 2014; Defrancesco, et al. 2018; Bernard, et al. 2014; Choudhary, et al. 2018; Kumar, et al. 2018; Francis, et al. 2017a).

2015. Economics Development Analysis Journal, EDAJ Volume 2.

Balmford, A., Green, R. E., \& Scharlemann, J. P. W. (2005). Sparing land for nature: exploring the potential impact of changes in agricultural yield on the area needed for crop production. Global Change Biology, 11(10), 1594-1605.

Bernard F, Van Noordwijk M, Luedeling E, Villamor GB, Sileshi GW, Namirembe S (2014) Social actors and unsustainability of agriculture. Curr Opin Env Sust 8:155-161. doi:10.1016/j.cosust.2014.01.002

Butsic, V., Baumann, M., Shortland, A., Walker, S., \& Kuemmerle, T. (2015). Conservation and conflict in the Democratic Republic of Congo: The impacts of warfare, mining, and protected areas on deforestation. Biological Conservation, 191, 266-273.

Central Bureau of Statistics of East Java in Numbers, 2020. https://jatim.bps.go.id/

Chandler, R. B., King, D. I., Raudales, R., Trubey, R., Chandler, C., \& Arce Chávez, V. J. (2013). A small-scale land-sparing approach to conserving biological diversity in tropical agricultural landscapes. Conservation Biology, 27(4), 785-795.

Choudhary M, Datta A, Jat HS, Yadav AK, Gathala MK, Sapkota TB, Das AK, Sharma PC, Jat ML, Singh R, Ladha JK (2018) Changes in soil biology under conservation agriculture based sustainable intensification of cereal systems in Indo-Gangetic Plains. Geoderma 313:193-

204. https://doi.org/10.1016/j.geoderma. 2017.10.041

Choudhary M, Rana KS, Bana RS, Ghasal PC, Choudhary GL, Jakhar P, Verma RK (2017) Energy budgeting and carbon footprint of pearl millet-mustard cropping system under conventional and conservation agriculture in rainfed semi-arid agro-ecosystem. Energy 141:10521058. https://doi.org/10.1016/j.energy.2 017.09.136 
Ciliberti, S., \& Frascarelli, A. (2018). The CAP 2013 reform of direct payments: Redistributive effects and impacts on farm income concentration in Italy. Agricultural and Food Economics, 6, 19.

Convention on Biological Diversity. (1992). Convention on biological diversity. Montreal, Canada: Secretariat of the Convention on Biological Diversity.

Das B, Singh A, Panda SN, Yasuda H (2015) Optimal land and water resources allocation policies for sustainable irrigated agriculture. Land Use Policy 42:527-537

Defrancesco, E., Gatto, P., \& Mozzato, D. (2018). To leave or not to leave? Understanding determinants of farmers' choices to remain in or abandon agri-environment schemes. Land Use Policy, 76, 460-470.

De Groot, R. (2006). Function-analysis and valuation as a tool to assess land use conflicts in planning for sustainable, multi-functional landscapes. Landscape and Urban Planning, 75(3-4), 175-186.

Ditzler, L., Komarek, A. M., Chiang, T. W., Alvarez, S., Chatterjee, S.A., Timler, C., Raneri, J., Estrada Carmona, N., Kennedy, G., Groot, J.C.J. (2019). A model to examine farm household trade-offs and synergies with an application to smallholders in Vietnam. Agricultural Systems Journal.

Ditzler, L., Klerkx, L., Chan-Dentoni, J., Posthumus, H., Krupnik, T. J., Ridaura, S. L., Andersson, J. A., Baudron, F., \& Groot, J. C. J. (2018). Affordances of agricultural systems analysis tools: A review and framework to enhance tool design and implementation. Agricultural Systems. https://doi.org/10.1016/j.agsy.2 018.03.006.

Dressler, W., de Koning, J., Montefrio, M., \& Firn, J. (2016). Land sharing not sparing in the "green economy": The role of livelihood bricolage in conservation and development in the Philippines. Geoforum, 76, 75-89.

Egan, J. F., \& Mortensen, D. A. (2012). A comparison of land-sharing and land-sparing strategies for plant richness conservation in agricultural landscapes. Ecological Applications, 22(2), 459-471.

FAO. (1989). Sustainable Development and Natural Resources Management. Twenty Fifth Conference, Paper C 89/2 Simp 2, Food and Agriculture Organization, Rome.

FAO. (2014). The state of food insecurity in the world.
Fischer, J., Abson, D. J., Butsic, V., Chappell, M. J., Ekroos, J., Hanspach, J., von Wehrden, H. (2014). Land sparing versus land sharing: moving forward. Conservation Letters, 7(3), 149-157.

Francis CA, Jensen ES, Lieblein BTA (2017a) Agroecologist education for sustainable development of farming and food systems. Agron J 109:23-32. doi:10.2134/agronj2016.05.0267

Francis C, Wiedenhoeft M, Dehaan R, Porter P (2017b) Education in agroecological learning: holistic context for learning farming and food systems. In: Wezel A (ed) Agroecological practices for sustainable agriculture: principles, applications, and making the transition. World Scientific Publishing Europe Ltd, London, UK, pp 395-418

Franzel, S., \& Houten, H. van. (1992). Research with farmers: lessons from Ethiopia.

Godfray, H. C. J., Beddington, J. R., Crute, I. R., Haddad, L., Lawrence, D., Muir, J. F., Toulmin, C. (2010). Food security: the challenge of feeding 9 billion people. Science, 327(5967), 812-818.

Grau, R., Kuemmerle, T., \& Macchi, L. (2013). Beyond "land sparing versus land sharing": environmental heterogeneity, globalization and the balance between agricultural production and nature conservation. Current Opinion in Environmental Sustainability, 5(5), 477-483.

Haris, Z.A., Agustar, A., Noer, M., \& Yulnafatmawita. (2015). Implementation of Corporate Social Responsibility (CSR) of Cement Factory: Partnership Program, Environmental Guidance, and National Company-Care. International Journal On Advanced Science, Engineering and Information Technology, 5(6), 501-505.

Haryanto, L. I., Masyhuri, M., \& Irham. (2018). The policy analysis matrix in measuring competitiveness of maize farming system in marginal areas. Jurnal Agro Ekonomi, 29(2), 244-260.

Jat HS, Datta A, Choudhary M, Sharma PC, Yadav AK, Choudhary V, Gathala MK, Jat ML, McDonald A (2019a) Climate smart agriculture practices improve soil organic carbon pools, biological properties and crop productivity in cereal-based systems of NorthWest

India.

Catena 
181:104059. https://doi.org/10.1016/j.cat ena.2019.05.005

Jat HS, Datta A, Choudhary M, Yadav AK, Choudhary V, Sharma PC, Gathala MK, Jat ML, McDonald A (2019b) Effects of tillage, crop establishment and diversification on soil organic carbon, aggregation, aggregate associated carbon and productivity in cereal systems of semi-arid Northwest India. Soil Till Res

190:128-

138. https://doi.org/10.1016/j.still.2019. 03.005

Jat HS, Kumar A, Sutaliya JM, Kumar S, Choudhary M, Yadvinder-Singh, Jat ML (2019c) Conservation agriculture based sustainable intensification of basmati rice-wheat system in North-West India. Arc Agron Soil Sci 65:1370

1386. https://doi.org/10.1080/03650340. 2019.1566708

Jat HS, Sharma PC, Datta A, Choudhary M, Kakraliya SK, Yadvinder-Singh, Sidhu HS, Gerard B, Jat ML (2019d) Re-designing irrigated intensive cereal systems through bundling precision agronomic innovations for transitioning towards agricultural sustainability in North-West India. Sci Rep 9:17929. https://doi.org/10.1038/s41598019-54086-1

Jat HS, Datta A, Sharma PC, Kumar V, Yadav AK, Choudhary M, Choudhary V, Gathala MK, Sharma DK, Jat ML, Yaduvanshi NPS (2018) Assessing soil properties and nutrient availability under conservation agriculture practices in a reclaimed sodic soil in cerealbased systems of North-West India. Arch Agron Soil Sci 64:531545. https://doi.org/10.1080/03650340.2 017.1359415

Kumar V, Jat HS, Sharma PC, Gathala MK, Malik RK, Kamboj BR, Yadav AK, Ladha JK, Raman A, Sharma DK, McDonald A (2018) Can productivity and profitability be enhanced in intensively managed cereal systems while reducing the environmental footprint of production? Assessing sustainable intensification options in the breadbasket of India. Agr Ecosyst Environ 252:132147. https://doi.org/10.1016/j.agee.2017 .10 .006
Kusumawardhani, D., Rahayu, A.Y., \& Maksum, I.R. (2015). The Role of Government in MSMEs: The Empowerment of MSMEs during the Free Trade Era in Indonesia. Australasian Accounting, Business and Finance Journal, 9(2), 23-42.

Kurniawati, F. \& Mukzam, M.D. (2017). The Implementation and Effect of Partnership Program and Community Development held by PT Pelabuhan Indonesian III (Persero) in SMEs Development (Case Study in Kampung Lawas Maspati Surabaya). Public Administration Journal, 50(2). 40-46.

Kurniasih, T.U. \& Rodhiyah. (2016). The Effectiveness of Partnership Program as the Form of Company Social Responsibility (CSR) in Fostered SMEs of PT Telkom Indonesia Regional 4 Semarang. Business Administration Scientific Journal, 5(4), 63-59.

Kremen, C. (2015). Reframing the land-sparing/landsharing debate for biodiversity conservation. Annals of the New York Academy of Sciences, 1355(1), 52-76.

Law, E. A., Meijaard, E., Bryan, B. A., Mallawaarachchi, T., Koh, L. P., \& Wilson, K. A. (2015). Better land-use allocation outperforms land sparing and land sharing approaches to conservation in Central Kalimantan, Indonesia. Biological Conservation, 186, 276-286.

Lee, J. S. H., Garcia-Ulloa, J., Ghazoul, J., Obidzinski, K., \& Koh, L. P. (2014). Modelling environmental and socio-economic trade-offs associated with land-sparing and land-sharing approaches to oil palm expansion. Journal of Applied Ecology, 51(5), 1366-1377.

Leventon, J., \& Antypas, A. (2012). Multi-level governance, multi-level deficits: The case of drinking water management in Hungary. Environmental Policy and Governance, 22(4), 253-267.

Liliyawati, L. \& Budhi. M.K.S. (2016). Factors Affecting Labor Absorption and Furniture Industry Efficiency in Denpasar City. EJournal of Economic Development of Udayana University, 5(8), 865-883.

Makate, C., Wang, R., Makate, M., \& Mango, N. (2016). Crop diversification and livelihoods of smallholder farmers in Zimbabwe: adaptive 
management for environmental change. SpringerPlus, 5(1), 1135.

Mertz, O., \& Mertens, C. F. (2017). Land sparing and land sharing policies in developing countriesdrivers and linkages to scientific debates. World Development, 98, 523-535.

Mentayani, I. \& Rusmanto, R. (2016). The Implementation of Corporate Social Responsibility to Partnership Program implemented in Fostered Partners of State-Owned Enterprises in South Borneo. Management Application Journal, 14(3), 481-491.

Miles, M. B., \& Huberman, A. M. (1984). Qualitative data analysis: A sourcebook of new methods. Beverly Hills, CA: Sage.

Nasikh. (2013). a Model of Collaborative Forest Resources Management To Improve the Prosperity of Poor Family Farmers in East Java. The Indonesian Journal of Geography, 45(1), 80. https://doi.org/10.22146/ijg.2408

Nasikh. (2014). Horizontal Management of Forest Resources to Enhance the Partnership and Account Ability in Pasuruan, East Java, Indonesia. 2(5), 685-688. Retrieved from www.ajouronline.com/index.php/AJHSS/articl e/view/1591

Nasikh. (2017). Institutional model and activities of destitute society around forest as an attempt to develop the sustainable and equitable forest in East Java, Indonesia. Periodica Polytechnica Social and Management Sciences, 25(1), 8-16. https://doi.org/10.3311/PPso.8536

Nasikh. (2018). An analysis of the local resources potential to achieve food security in jombang and probolinggo regencies East Java Indonesia. Iranian Economic Review, 22(2), 135-148. https://doi.org/10.22059/IER.2018.66161

Nasikh, \& Hakim L, M. (2015). The Regional Government Policy to Maintain the East Java Food Security to Achieve the Imported RiceFree. Joint Research of Balitbang of East Java Province and the State University of Malang. Research Finding Report.

Phalan, B., Onial, M., Balmford, A., \& Green, R. E. (2011). Reconciling food production and biodiversity conservation: land sharing and land sparing compared. Science, 333(6047), 1289-1291.

Phelps, J., Carrasco, L. R., Webb, E. L., Koh, L. P., \& Pascual, U. (2013). Agricultural intensification escalates future conservation costs. Proceedings of the National Academy of Sciences, 110(19), 7601-7606.

Pirard, R., \& Belna, K. (2012). Agriculture and deforestation: Is REDD+ rooted in evidence? Forest Policy and Economics, 21, 62-70.

Pradnya, P.H. (2014). The Effect of SMEs to the Regional Economic Development. Wacana, Volume 17 Number 2.

Pujiati, A. \& Imron, M. (2020). The Effect of Industrial Existence on the Environment and Socio-Economy. Economics Development Analysis Journal, 9 (1), 12-22.

Rahmini. S.( 2017). The Development of SMEs in Indonesia. Cano Ekonomos Scientific Journal Volume 6 Number 1.

Rai, N. D., \& Bawa, K. S. (2013). Inserting politics and history in conservation. Conservation Biology, 27(2), 425-428.

Rasyid, Abdurrahman. (2016). The Analysis of Leading Agricultural Sector in Kediri Regency in 2010-2014. Economic Development Journal Vol. XIV, No. 02

Reed, M. S., Graves, A., Dandy, N., Posthumus, H., Hubacek, K., Morris, J., Stringer, L. C. (2009). Who's in and why? A typology of stakeholder analysis methods for natural resource management. Journal of Environmental Management, 90(5), 1933-1949.

Report of the World Industry Conference on Environmental Management. (1984). Particularly the principles adopted by OECD in 1985 as a clarification of the OECD Guiding Principles for Multinational Enterprises in International Legal Materials. 25(1).

Rodhiyah, (2015). The Social and Economic Effects of SMEs in Convection Industry in Semarang City. Social Science Journal, Volume 14 Number 1.

Smith A, Snapp S, Chikowo R, Thorne P, Bekunda M, Glover J (2017) Measuring sustainable intensification in smallholder agroecosystems: a review. Glob Food Secur 12:127-138. doi:10.1016/j.gfs.2016.11.002

Suprayitno, H., Hardjomidjojo, H., \& Sarma, M. (2013). Partnership Program Loan to Improve the Performance of Fostered Partner of PT Sucofindo (Persero). Management Journal IKM, 8(1), 9-19.

Susilo, S.R. (2014). The Effectiveness of Partnership Program Implemented by PT KAI Daop I Jakarta to Develop the Small and Medium- 
sized Business. Public Policy and Management Journal, 2(1). 285-293.

Suryana, A. (2005). The Sustainable Agricultural Development as the Signature of the National Development. A Paper to Be Presented in the Seminar of Sustainable Agricultural System to Support the National Development on 15 February 2005 in Universitas Sebelas Maret, Solo.

Tadesse, G., Zavaleta, E., Shennan, C., \& FitzSimmons, M. (2014). Prospects for forestbased ecosystem services in forest-coffee mosaics as forest loss continues in southwestern Ethiopia. Applied Geography, 50, 144-151.

The Government Regulation. The Establishment and Functional Shift of the Sustainable Food Agricultural Land.. 2011.

The Government Regulation. The Incentive of the Sustainable Food Agricultural Land Conservation. 2012.

Tscharntke, T., Clough, Y., Wanger, T. C., Jackson, L., Motzke, I., Perfecto, I., Whitbread, A. (2012). Global food security, biodiversity conservation and the future of agricultural intensification. Biological Conservation, 151(1), 53-59.

Van Veldhuizen, W.-B., \& Waters-Bayer, A. (n.d.). A. and de Zeeuw, H. 1997. Developing Technology with Farmers. A Trainer's Guide for Participatory Learning. Zed Books Ltd. London.

Waridin, Rizky, K. D. S., Indah, S., Kesi, W., Evi, Y. P. (2019). Economic Evaluation on the Application of Collaborative Forest Management (CFM). Economics Development Analysis Journal, 8 (4), 292-301.

Wijaya, I.R. \& Yuniati, T. (2014). The Partnership Program and Community Development Implementation in Woven Sarong Business by PT Telkom Indonesia. Scientific and Management Research Journal, 3(4), 1-15.

Windy, D. (2014). Indonesian's Food Security is Weak in ASEAN. Retrieved August 7, 2014, from www.m.mediaindonesia.com

Wirawan, M.D. \& Arka, S. (2015). The Effectiveness of BTDC Partnership Program and Its Effect to SME Income and Labor Absorption in Badung Regency. E-Journal of Economic Development of Udayana University, 4(10), 1247-1275.

Yudha and Wahyu. (2013). Economic Structure Transformation in Siak Regency in 20012010. Economic Journal Vol. XXI, No. 01

Zulfikar, W. (2017). The Social, Economic, and Political Effects in Kertajadi Airport
Development in Majalengka Regency. Caraka Prabu Journal, Volume 01 Number 01. 